\title{
Resituating Erving Goffman: From Stigma Power to Black Power
}

\author{
Abstract
}

This paper offers a critical re-reading of the understanding of stigma forged by the North American sociologist Erving Goffman in his influential Stigma: Notes on the Management of a Spoiled Identity (1963). One of the most widely read and cited sociologists in history, Goffman was already famous when Stigma was published in 1963. His previous books were best-sellers and Stigma alone has sold an astonishing 800,000 copies in the fifty years since its publication. Given its considerable influence, it is surprising how little sustained engagement there has been with the historicity of Goffman's account. This paper resituates Goffman's conceptualisation of stigma within the historical context of Jim Crow and the Black freedom struggles that were shaking "the social interaction order" to its foundations at the very moment he crafted his account. It is the contention of this paper that these explosive political movements against the "humiliations of racial discrimination' invite revision of Goffman's decidedly apolitical account of stigma (Robinson, 2000, p. 318). This historical revision of Goffman's stigma concept builds on an existing body of critical work on 'the relationship between race, segregation and the epistemology of sociology within the United States' (Bhambra, 2014). Throughout, it reads Goffman's Stigma through the lens of "Black Sociology", a field of knowledge that here designates not only formal sociological scholarship, but political manifestos, journalism, creative writing, oral histories and memoirs. It is the argument of this paper that placing Goffman's concept of stigma into critical dialogue with Black epistemologies of stigma allows for a timely reconceptualisation of stigma as governmental technologies of de-humanisation that have long been collectively resisted from below.

Keywords: stigma, racism, Goffman, Civil Rights, Jim Crow, Black Power 


\title{
Resituating Erving Goffman: From Stigma Power to Black Power
}

\author{
Long we've borne the nation's
}

Shame.

J. Thompson ‘Exhortation' 1933 (in Kelley, 1996, p. 103).

I ask to be considered. I am not merely here and now, sealed into thingness. I am for somewhere else and for something else (Fanon, 2008, p. 170).

\section{Stigma: A History Lesson}

In January 1960, a Black teenager called Joseph McNeil travelled back from a Christmas visit with his family in New York, to North Carolina Agricultural and Technical State University in Greensboro. When McNeil got back to campus he described the bus journey to his friends: In Philadelphia, I could eat anywhere in the bus station. By Maryland, that had changed; by the time I arrived in Richmond, Virginia I was refused a hotdog at a food counter reserved for whites. 'It was a degrading experience; three hours ago I was a human being... three hours later... some kind of pariah' (Cerese \& Channing, 2003). Travelling from the Northern to the Southern states in 1960 meant crossing, in Erving's Goffman's terms, from one "social interaction order" into another. Arriving in the South in 1960 meant immersion in the spatial politics of white supremacy, manifest in the Jim Crow signs that segregated social spaces and in unspoken 'customs', rules, rituals and codes 'designed to degrade and divide' (Davis, 2004, p. 496). McNeil and three teenage friends, Franklin McCain, David Richmond and Jibreel Khazan, ${ }^{i i}$ had spent the evenings of their first term at university discussing Ghandi, Langston Hughes, Martin Luther King, and Jim Crow -- a period 'of institutionalized violence against African Americans' that had lasted by then for close to a century (Bhambra, 2014, p. 480). They had talked long into the night about the failures of the Civil Rights Movement to effect meaningful change and the quotidian humiliations of living under white supremacy. Furious after his degrading bus journey, McNeil persuaded his friends to take direct action. On 1 February, the four went into the Woolworths store on South Elm Street in Greensboro and sat down at the "Whites only" lunch counter.iii They asked for coffee. The 
waitress refused to serve them: 'we don't serve Negroes here' (Langer, 2014). The police were called, an officer arrived, 'He took his knife stick out. He took his billy club and began to hit it on his hand' (Cerese \& Channing, 2003). Taking their place in a long history of Southern Black freedom fighters, the four refused to move from their seats. The Greensboro four returned to Woolworths lunch counter every day that week accompanied by growing numbers of students from A\&T, Bennett College (a Black liberal arts college for women), and Dudley High School (then a segregated Black school). By 6 February, 1000 students were sitting-in at Greensboro Woolworths lunch counter. These initially minor 'dramaturgical' challenges to segregation escalated into the largest Black resistance movement in the history of the United States (Goffman, 1956).

The sit-in protests garnered extensive national television news coverage. By 1958 over $80 \%$ of American homes had television sets, and by 1960 the use of $16 \mathrm{~mm}$ film and the development of wireless audio recorders, transformed the ability of television journalists 'to capture volatile demonstrations as they unfolded' (Fleming \& Morris, 2015, p. 113). ${ }^{i v}$ As a consequence of this rapidly growing television audience, and technical advances in shooting news footage, 'the sit-ins provided the nation with a unique experiment in moral theatre, where Black protestors (at times with white allies) nonviolently withstood verbal and physical abuse.' (Joseph, 2014, p. 19). ${ }^{\vee}$ Anne Moody, then a sociology student at Tougaloo College, described the scene at a sit-in at a Woolworths lunch counter in Jackson, Mississippi:

the white students started chanting all kinds of anti-Negro slogans. We were called a little bit of everything. The rest of the seats except the three we were occupying had been roped off to prevent others from sitting down. A couple of the boys took one end of the rope and made it into a hangman's noose. Several attempts were made to put it around our necks. The mob started smearing us with ketchup, mustard, sugar, pies, and everything on the counter. [...] a Negro high school boy sat down next to me. [...] the word "nigger" was written on his back with red spray paint (Moody, 1968, p. 238)

Being Black in the United States in 1960 was to be 'smeared with the stigma of "racial inferiority"' (Haywood, 1948, p. 138). By putting their bodies in white-only spaces, these young people sought to dramatise 'the studied humiliations' of Jim Crow (Du Bois [1903], 2015, p. 160). Protesting the political and economic terrorism of white supremacy came at a price; people were heckled, intimidated, beaten, arrested and expelled from schools, colleges and jobs. As then student activist (and later sociology Professor) Joyce Ladner notes: 'It was very, very difficult to continue 
because the local police and all the towns had almost crushed us. They were closing in like... They murdered people, they beat people' (Ladner, Ladner \& Mosnier, 2011). What motivated young people to participate in the face of these 'terrible beatings, brutalities' was often a deeply personal need to express the anguish of living with anti-Black racism (Kelley, 1996, p. 79). These 'subversive demands for a dignified life free from harassment' (Gilroy, 2002, p. xiii) were acts of resistance against what Malcolm $X$ described as the 'psychological and physical mutilation that is an everyday occurrence in our lives' (X, 1964, p. 2). As McCain reflects 'it really started out as a personal thing... we didn't like the idea of not having dignity and respect... and decided it was really up to us to find a solution to this thing we were suffering with' (Boyd, 2004). McCain described the Woolworths protest as a reparative act: 'almost instantaneously after sitting down on a simple dumb stool, I felt so relieved, I felt so clean', 'a feeling of total freedom' (Cerese \& Channing, 2003). Similarly, when Jibreel Khazan was asked what moved him to act he replied 'something had to be done to remove the stigma' (Khazan, N.D., my emphasis).

\section{Introduction}

Through the examination of the history of a particularly influential sociological concept, stigma, this article responds to calls for a reconstruction of 'the historical narratives that inform sociological conceptions of the contemporary world' (Bhambra, 2014a, p. 1). It emerges out of an ongoing Leverhulme funded research project on the Sociology of Stigma (2015-2018) which seeks to develop new historical understandings of stigma (as) power. One of the major aims of this project is to supplement the often individualistic, ahistorical and politically anesthetised conceptualisation of stigma which dominates within the social sciences, with richer historical understandings of the social and political function of stigma as an instrument of social policy and 'component of the state's coercive apparatus' (Davis, 2004, p. 494). In order to better understand the "political economy of stigma", I am researching the long penal history of stigma as a practice of social control, stretching from the penal tattooing of slaves in the Greek and Roman Empires, through to the badging of the poor in Industrial Britain and the stigmatisation of migrants in contemporary political rhetoric (Tyler, 2017; Tyler, forthcoming). This paper is guided by this research but the specific focus here is on the emergence of stigma as a sociological concept in the mid-twentieth century. ${ }^{\text {vi }}$ To this end, the paper reappraises the understanding of stigma forged by the North American sociologist Erving Goffman in his influential Stigma: Notes on the Management of a Spoiled Identity (1963). The reason for returning to Goffman is that despite many subsequent refinements of his account, this short book established the conceptual understanding of stigma that continues to buttress contemporary sociological thinking. 
This critical reading of Goffman's Stigma is an urgent one in the context of the wider movement to "decolonize" the sociological canon. Decolonising sociology necessities the development of a 'deep historical consciousness' and a commitment to 'unlearning' the epistemological foundations of the discipline, in order to confront 'more candidly the myriad of effects and consequences' of the concepts, vocabularies and methods which have shaped the discourses and practices of sociology since its invention as a science in the mid-nineteenth century (West [1987], 2016). The historical revision of Goffman's stigma concept that follows builds on a growing body of critical work on 'the relationship between race, segregation and the epistemology of sociology within the United States' (Bhambra, 2014, p. 472). It is not only, as Gurminder Bhambra notes, that 'dominant historiographies have been silent' on the segregation of sociologists of colour and the sociology of racialisation and racisms from mainstream canons, but that this has had a profound epistemological and political impact on sociological knowledge (Bhambra, 2014a, p. 1-2). This paper draws particular inspiration from Roderick Ferguson's Aberrations in Black: Towards a Queer of Color Critique (2004). Concerned with 'the strategies of power that are immanent in canonical sociology's will to knowledge', Ferguson focuses on mid-twentieth century North American Sociology, and the ways in which 'techniques of racial domination' 'are obscured through the language of liberal progress' (Ferguson, 2004, p. 55, p. 63). Reading sociological classics alongside Black American fiction from the same period, Ferguson examines how sociologists produced pathological knowledge about Black culture which functioned as 'an epistemological counter-part' to official forms of state racism. Sociology, he argues, was 'the supplicant of the American state' (p. 81) employed to regulate and legislate (against) non-white populations. This paper brings Ferguson's insight to bear on both the concept of stigma and practices of stigmatisation, by rethinking stigma as a technology of racism.

One of the most widely read and cited sociologists in history, Goffman was already famous when Stigma was published in 1963. His previous books Presentation of Self in Everyday Life (1956) and Asylums: Essays on the Social Situation of Mental Patients and Other Inmates (1961) were bestselling titles, an unusual achievement for academic sociological texts. Stigma alone has sold an astonishing 800,000 copies in the fifty years since its publication. Given the considerable influence of Stigma, it is surprising how little sustained engagement there has been with the historicity of Goffman's conceptualisation of stigma; Heather Love's work on Goffman's "stigma archive" being a notable exception (see Love, 2010, 2013). Reading Goffman historically isn't an easy task for as Fredric Jameson notes, his work is 'punctuated by frequent disclaimers that his material is drawn only from our own society and that his findings are therefore not necessarily binding on other 
social forms'; an admission which is 'not so much an invitation to comparative research and to a more genuinely historical approach... as it is a dismissal of those perspectives' (Jameson, 1976, p. 124). Despite the difficulty of reading Goffman against the grain, this paper resituates his conceptualisation of stigma within the historical context of the Black freedom struggles which were shaking "the social interaction order" to its foundations at the moment he crafted his account. It is one of the central contentions of this paper that the explosive political movements against what Cedric Robinson termed the 'humiliations of racial discrimination' (Robinson, 2000, p. 318) in the 1960s invites revision of Goffman's decidedly apolitical account of stigma.

Throughout it reads Goffman's stigma concept through the lens of Black Sociology, a field of knowledge which here designates not only formal sociological scholarship, but political manifestos, journalism, creative writing, oral histories and memoirs. It draws on the resources of this "Black stigma archive" to challenge Goffman's account. In doing, this paper troubles 'the conceptual matrix' that has isolated 'the study of race and racism' from sociological (and social psychological) accounts of stigma (Magubane, 2016, p. 371). It also reveals how bringing racism to the front and centre of sociological understandings of stigma, transforms existing understandings of stigma. In particular, it is the argument of this paper that placing Goffman's concept of stigma into dialogue with Black epistemologies of stigma allows for a reconceptualisation of the social and political function of stigma as a governmental technology of 'racialized capitalism' (see Bonds \& Loyd, this issue).

\section{Struggles in the Interaction Order}

What distinguishes Goffman's work is his career-long focus on social interaction defined as 'social situations... in which two or more individuals are physically in one another's response presence' (Goffman, 1982, p. 2). As he notes in 'The Interaction Order' (1982), his posthumously published Presidential Address to the American Sociology Association: 'my concern over the years has been to promote acceptance of this face-to-face domain as an analytically viable one -- a domain whose preferred method of study is microanalysis' (p. 2). The interactional spaces which Goffman was interested in studying extended to all conceivable public settings: 'a local bar, a small shop floor, a domestic kitchen... factories, airports, hospitals, and public thoroughfares' (p. 4). Goffman was interested in observing these 'behavioural settings' (p. 4) for what they reveal about the rules, norms, conventions and procedures that allow for orderly social interactions to take place. Those familiar with Goffman's oeuvre will be reminded of his dramaturgical understanding of the interaction order as 'a natural theater', with a front and back stage, in which people perform 
anticipated and prescribed social roles (p. 4). He was particularly interested (and I will argue politically invested) in how social order is maintained, including why individuals 'go along with current interaction arrangements' even in contexts where they might 'resent' or 'resist' the costs of social arrangements (p. 5). Goffman's concern with 'shared cognitive presuppositions' and 'selfsustained restraints' that underpin human interactions inevitably raises questions about what kinds of structures and values shape the interactions that comprise social worlds (p. 4). As Goffman states, 'questions do arise when we consider the fact that there are categories of persons - in our own society very broad ones - whose members constantly pay a very considerable price for their interactional existence' (p. 6). However, while Goffman acknowledges these questions, he refuses to dwell on them. Rather, he argues that the work of the micro-analyst necessitates a "bracketing off" of the economic and political imperatives that structure behavioural settings. One of the 'warrants' he offers for this elision is that his approach is not 'informed by a concern over the plight of disadvantaged groups' (p. 2). What is striking about this statement is that Goffman's career as a sociologist spanned some of the most tumultuous decades of resistance by 'disadvantaged groups' - including Black people, women, disabled people, 'mad' people and queers - to the dominant social order in US history. More than this, the grassroots resistance movements which characterised this period were taking place within the very 'behavioral settings', and involved conflicts in exactly the kinds of 'service transactions', which were, ostensibly, at the very centre of Goffman's sociological interest (p. 2, p. 7). As Stokely Carmichael put it in 1966 ' I am black. I know that. I also know that while I am black I am a human being, and therefore I have the right to go into any public place' (Carmichael, 1966, my emphasis). ${ }^{\text {vii }}$

Two months after Greensboro electrified the Civil Rights Movement from below, the formation of the Student Nonviolent Coordinating Committee (SNCC) saw young people's actions against racial segregation extended to "Freedom Rides" which challenged segregation on interstate travel, kneel-ins at segregated churches, sleep-ins at segregated motels, swim-ins at segregated pools, wade-ins at segregated beaches, read-ins at segregated libraries, play-ins at segregated parks, watch-ins at segregated cinemas and theatres, wait-ins at housing developments, chain-ins at city halls and participation in rent-strikes (Boggs, 2011). ${ }^{\text {vii }}$ By the spring of 1960 it was estimated that fifty thousand people had participated in "interactional" forms of political resistance against the violent regimes of racial stigma which characterised Jim Crow. By 1963 'the southern struggle had grown from a modest group of Black students demonstrating at one lunch-counter to the largest mass movement for racial reform and civil rights in the 20th century' (Younge, 2013). It was in the 
midst of these political struggles in "the interaction order" that Goffman crafted his concept of stigma.

Between 1960-1963 Goffman was teaching a course called 'Deviance and Social Control' at the University of Berkley, and Stigma emerged out of his lectures for his course. While teaching at Berkley Goffman would have been acutely aware of the Black freedom struggles which were exploding all around in 'sit-ins, marches, protest rallies and urban upheavals' (Collins, 2007, p. 585). ${ }^{\mathrm{ix}}$ As indicated above, newspaper images and television footage of 'chanting demonstrators being sprayed by fire hoses and attacked by dogs, freedom riders being abused, sit-in participants being taunted or beaten, and small Black children requiring military escorts to enter public schools' made for powerful viewing in this period (Macdonald in Robinson, 1997, p. 145). Moreover, as a consequence of the sit-in movement, the 'pernicious de facto segregation of the Urban North' was increasingly seen through the lens of the 'codified racial discrimination' of Jim Crow (Taylor, 2016, p. 37). From the spring of 1960, Berkeley students were picketing hotels and shops which were known to practice racial discrimination in their employment practices in solidarity with southern sit-in movements (Freeman, 2004). We know that this anti-racist politics leaked into Goffman's classroom, as the sociologist Gary Marx, then a student in Goffman's 1961 'Deviance and Social Control' class, recalls:

At the end of the last class session a black student said "this is all very interesting Professor Goffman, but what's the use of it for changing the conditions you describe?" Goffman was visibly shaken. He stood up, slammed shut the book he had open on the desk and said "I'm not in that business" and stormed out of the room (Marx, 1984).

In what follows, I examine what happens to Goffman's account of stigma when we take seriously the question of this unnamed Black studentx: 'what's the use of it for changing the conditions you describe?'

\section{Social Relations without Power Relations}

In the opening pages of Stigma, Goffman offers a working definition of stigma as, 'an attribute that is deeply discrediting' $(1986$, p. 2) and 'the situation of the individual who is disqualified from full social acceptance' (Preface). However, what is most novel and influential about the definition of stigma he proposes, is the ways in which Goffman roots stigma in his existing understanding of social identities as 'perspectives' produced in interactional settings (p. 138). While stigma might 
be experienced as emanating from the body of the stigmatised, in fact stigma describes a relation between normal and stigmatised persons. What he means by this is that people acquire stigma in their exchanges with other people - be this a look, a glance, a comment or a more overt form of discrimination such as name-calling. Goffman's understanding of stigma, as something produced in social settings, pivots on the existence of a social consensus about "what is normal". For Goffman, society "works" and "coheres" to the extent that members of society implicitly understand and share, or at least accept, the norms in operation in a given social context. So, in social interactions, Goffman argues, 'there is some expectation on all sides that those in a given category should not only support a particular norm but also realize it' (p. 6). Stigma describes a particular kind of negative social relation then, as it arises when an individual fails to realise 'a particular norm' (ibid.). Further, stigma not only describes a relation between people, but also a relation of self to self. Goffman argues that it is through processes of socialisation that an individual 'learns and incorporates the stand-point of the normal' and in doing understands how they are likely to be placed in a stratified order of normal-stigma positionalities (p. 32). Through this psycho-social process, people judge themselves against incorporated norms and anticipate 'the standards against which they fall short' (p. 32). In short, rather like Pierre Bourdieu's relational theory of social class, for Goffman social identities are not properties of a person, but emerge in encounters between social actors and in doing become incorporated as part of oneself. However, unlike Bourdieu, his account of stigma as a relational classification excludes questions of how social relations are structured through power.

Where do these norms come from? Again, Goffman anticipates but doesn't this answer this question, stating on the first page of his book: 'Society establishes the means of categorizing persons and the complement of attributes felt to be ordinary and natural for members of these categories' (p. 2). Towards the end of Stigma, he admits that stigmatisation is historically specific in the forms it takes (p. 138), notes that 'shifts have occurred in the kinds of disgrace that arouse concern', and implicitly acknowledges that stigma functions 'as a means of formal social control' (p. 139). However, he expresses little curiosity about where norms come from, what they prescribe, what the effects of these prescriptions might be, or how they might be challenged or transformed. Rather, he is concerned with detailing the more abstract operations of the system within which face-to-face interactions take place, in smooth or disordered ways. That is, his interest is in how social rules work rather than in what they proscribe. So while a relational understanding of stigma is at the core of Goffman's account, his understanding of normal-stigma relations is divorced from power relations-both the macro-level structural power relations of, for 
example, Capitalism or Patriarchy, or the power inflected micro-aggressions of everyday interactions. Fredric Jameson suggests that this suspension of questions of power is deliberate, for Goffman's ambition is 'to evolve abstractions which hold for all social situations', rather than to develop an understanding which is 'concrete and historically determinate' (Jameson, 1976, p. 129). It is possible to read power back into Goffman, and indeed this is what many sociologists who draw on his stigma concept have subsequently done, by thinking about stigma as a form of oppression or discrimination. However, it is the contention of this paper that thinking with this absence of power in Goffman remains important for understanding some of the remaining limitations of stigma as a conceptual tool for sociology. Employing Greensboro and the challenging question of Goffman's student as I guide, I want to consider what 'this ambition to evolve' an abstract understanding of stigma which might 'hold for all social situations' implies in terms of Goffman's methodology (Jameson, 1976, p. 129). I ask what it means to argue that society informs stigma categorisations in advance of interactional encounters without reference to, for example, colonial histories of power. And I want to reflect on how the structural absence of questions of power has shaped subsequent understandings of what stigma is, what stigma does and what stigma is for.

\section{Atrocity Tales: Goffman's Methods}

Despite his career-long concern with social interaction, Stigma is not grounded, as are some of Goffman's earlier studies such as Asylums (1961), or his PhD research in a Shetland Islands community which formed the basis of The Presentation of Self in Everyday Life (1956), in original ethnographic research. Indeed, despite being recognised as 'one of the founding figures of microsociology', and despite his self-presentation as pioneer of observational methods, his 'links to both ethnography and empiricism are rather tenuous, since he rarely engaged in traditional fieldwork and drew on both fictional literary texts and fabricated anecdotes for his evidence' (Love, 2013, p. 419). Goffman states that his objective in Stigma is to explore what a burgeoning psychological literature on stigma - but 'especially popular work' - might 'yield for sociology' (Preface). As Love details, it transpires from his footnotes that what Goffman means by 'popular work' is memoirs and biographies, letters and newspaper articles, 'lightly fictionalized [medical] case histories, human interest stories, and counterfactuals' (Love, 2013, p. 420). Indeed, Stigma opens with an epigraph, a fictional letter written by a 16-year-old girl who was 'born without a nose' to a newspaper 'agony aunt', which Goffman has taken from Nathaniel West's bleak comic depression-era novel Miss Lonelyhearts (1933). Goffman's use of this fictional epigraph has been interpreted as signalling compassion (Taylor, Bogdan \& DeVault, 2016, p. 176). However, given 
West's 'ironic' and 'dispassionate' treatment of 'emotionally and politically charged material' in this novel, it seems more likely that Goffman is making a playful statement about his own cool and detached approach to stigma (Love, 2013, p. 423). Indeed, I would argue that his use of this epigraph is best understood as a dry joke: the punchline being, as Goffman will argue at the end of Stigma, that 'we normals' might, just like the antihero in West's novel, find ourselves switched into the role of the stigmatised (Goffman, 1986, p. 5).

Stigma draws together a heterogeneous and eclectic archive of writing about blindness, facial deformities, cripples, amputees, alcoholics, gentleman criminals, ex-cons, prostitutes, homosexuals, the "mentally deficient", "the mad", anti-Semitism and anti-Black racism. Goffman describes his reading method as 'an exercise' in 'marking off the material on stigma from neighboring facts' and 'showing how this material can be economically described within a singular conceptual schema' (Preface). Love argues that this 'marking off' of 'facts' necessitates what she describes (approvingly) as 'thin description' (Love, 2013). ${ }^{\mathrm{xi}}$ What this method amounts to in practice is that there is often no discernible difference in how Goffman deploys, for example, an extract from a clinical account of a facial disfigurement, or a personal memoir or fictional account on the same topic. Certainly, he rarely introduces the authors of the materials he quotes from in his text, but rather substitutes particular accounts of stigma in his text with abstract "stigma figures”, such as 'a blind writer', 'a multipole sclerotic', 'a cripple', 'a prostitute', 'a homosexual', 'a Negro', 'a Jew' (Goffman, 1986). This abstraction produces the 'stylistic effect, of impartial "realism"' (Schweik, 2014). It is telling in this regard that Stigma is sometimes misread as based on Goffman's own first-hand observational research. What I want to draw attention to here is the politics of a method which deliberately eschews contextual information in this way.

What is veiled through this method of abstraction are the particular genres and aesthetics of the writing he draws upon, and the multiple perspectives encoded within these texts. Most significantly, in suppressing 'neighboring facts' Goffman erases the original intentions which might have motivated what is often confessional writing about stigma (Goffman, 1986, Preface). As noted, this suppression of authorial intention is deliberate on Goffman's part, for as he explains his account of stigma is not written for 'them', and it is not 'informed by a concern over the plight of disadvantaged groups' (1986?, p. 2). This point is underlined by his acerbic characterisation of some of the literature he draws upon as 'atrocity tales' written by 'stigma professionals' and 'heroes of adjustment' who seek to 'present the case for the stigmatized' (1986, p. 25). In short, Stigma draws on the writing of people who understood themselves in various ways as stigmatised (or are concerned about the fates of stigmatised people) but it fails to engage with the authors of 
this stigma data as 'knowers' or understand these confessional literatures as knowledge. On the contrary, Goffman's method of abstraction proceeds from what Kristie Dotson has described as 'an active practice of unknowing' (2011, p. 243).

It is important to note at this juncture that Stigma was written during a resurgence in confessional writing in US and wider European culture. Indeed, this "confessional turn" was central to social and political struggles of the period, beginning with the Civil Rights Movement and extending to feminist, queer, disability and anti-psychiatry movements (Goffman's Asylums played a central role in the later). Goffman acknowledges the 'current literary fashion' for confessional writing, self-help literature and 'advice to the stigmatized' in which 'deeply hidden sores are touched upon and examined' (1986, p. 112). He dismissively cites James Baldwin in a footnote as an example of 'material of this kind in regard to Negroes' (fn. 18, p. 112). At the same time, he veils over any of the reformist, consciousness-raising and/or political intentions of these 'atrocity tales' (p. 25). More than this, by transforming the authors of these stigma experiences into abstract figures -such as "negroes" in the aforementioned footnote about Baldwin -- Goffman enacts a 'testimonial quieting' (Dotson, 2011, p. 242) which mimics the dehumanising effects that the concept of stigmatisation describes. Goffman's reproduction of stigma in his writing, illustrates how stigma is a relation characterised by the relative power of "the normal" to silence, constrain and misrepresent "the other". The argument I am signalling here, is that reconceptualising stigma as a political economy of (de)valuation requires critical methods which are rooted not in the imagined "neutral" observational methods of the sociologist, but in peoples' struggles against the social structures that produce them as 'markedly inferior' (Du Bois, 1916, p. 86).

\section{The Stigma of Disability}

While this paper focuses on racial stigma, or more precisely stigma as another name for racism, I want to note at this juncture the understanding of stigma developed by disabled people in the early 1960s. In particular, I want to draw attention to the groundbreaking collection, Stigma: The Experience of Disability (1966), a series of autobiographical essays written by physically disabled people and edited by activist and writer Paul Hunt. What Hunt develops, through the curation and editing of this extraordinary collection of essays, is a multi-perspectival account of stigma from below. Indeed, in his contribution to this collection, 'A Critical Condition', Hunt argues, in a thinly veiled critique of Goffman, that stigma should not be theorised from the perspective of "normals" but from 'the uncomfortable, subversive position from which we act as a living reproach to any 
scale of values that puts attributes or possessions before the person' (Hunt, 1966, p. 159). In this essay, Hunt develops an understanding of stigma as a technology of disablement which stratifies people along a differential axis of in/humanity. Hunt's concept of stigma emerged from his concern with the ways in which stigma legitimated the segregation of disabled people from mainstream society. It is stigma, he argues, which allows disabled people to be perceived as 'unfortunate', 'useless', 'tragic' and 'abnormal' and thus undeserving of the rights or considerations of 'normal' able-bodied citizens (Hunt, 1966). Indeed, Hunt composed Stigma (1966) in a residential home in England where he was incarcerated against his will. ${ }^{\text {xii }}$

All my adult life has been spent in institutions amongst people who, like myself, have severe and often progressive physical disabilities. We are paralysed and deformed, most of us in wheelchairs, either as the result of accident or of diseases like rheumatoid arthritis, multiple sclerosis, muscular dystrophy, cerebral palsy and polio (Hunt, 1966, p. 145).

Hunt's understanding of stigma as a political economy emerges from the longer penal history of stigma (Tyler 2017: Tyler, forthcoming), as a cruel system of classification which marks out categories of people in order to impede their freedom and mobility. Further, his understanding of the relationship between stigma and segregation - for his was an anti-segregationist disability politics -- was directly inspired by the US Civil Rights Movement. While, as Hunt notes, the 'injustice and brutality suffered by so many because of racial tension makes our troubles as disabled people look very small', the dehumanisation of disabled people 'stirs in me a little of the same anger' which 'James Baldwin reveals in The Fire Next Time': a rather different reading of Baldwin and his centrality to freedom struggles against stigma than that suggested by Goffman (Hunt, 1966, p. 153). As Hunt concludes, stigma is a vital terrain of political struggle and 'we who are disabled are deeply affected by the assumptions of our uselessness that surround us. But it is vital that we should not accept this devaluation of ourselves' (Hunt, 1966, p. 149). While I cannot do justice to Hunt's pivotal contribution to disability activism and scholarship here, it is important to note the foundational role his conceptualisation of stigma as a pivotal force in the social segregation of disabled people played in the development of the social model of disability, and the policy and attitudinal changes which followed. Sadly, it is Goffman's, and not Hunt's, Stigma which is the most cited text in disability studies today. ${ }^{\text {xii }}$

\section{Professor Normal}


The problems I have identified with Goffman's methods, his suppression of questions of power, and his silencing of the perspectives of the "stigma knowers" he draws upon, are embedded within the very structure of his stigma concept. To further illustrate this, I want to briefly return to the status of norms in Stigma. As feminist, queer and critical race theorists have elaborated, ${ }^{\text {xiv }}$ it is often by unpacking norms that we get to the crux of the problem, the problem here being how Goffman's "neutral" sociological account of stigma in 1963 reproduces what Du Bois described as the 'National Stigma' of racism (Du Bois, 1916, p. 86).

Goffman uses the terms "norms", "normal" and those he designates as 'we normals' in multiple ways (1986, p. 5). At some points in Stigma norms seem to designate ideals 'and standards'; at others norms refer to foundational social rules which precede all social interactions; and at others norms are imagined as more akin to perceptual frames - the social optics - through which we perceive others (p. 128). In all these cases, norms describe accepted rules, conventions and ways of seeing. Indeed, Goffman is emphatic that 'a necessary condition for social life is the sharing of a single set of normative expectations by all participants' (p. 127-8, my emphasis). The normal human being is also used to mark the authorial position of Goffman, the 'neutral' sociological observer, in the text, while the address 'we normals' is employed several times in Stigma as a proxy for the imagined readers of his book. What "we' -- his readers - are invited to imagine we have in common with the authorial ' $l$ ', is a shared normality. In short, while Goffman argues that stigma is relational, his stigma concept is crafted from the authorial position of 'the normal human being', the powerful positionality of one who attributes stigma to those imagined as failing preagreed social norms of appearance or behaviour. So while, as noted above, his account of stigma draws on the experiential knowledge of stigmatised people, Goffman mediates this stigma knowledge through the perspective of 'we normals' (p. 5). As he writes, 'norms regarding social identity pertain to the kinds of role repertoires or profiles we feel it permissible for any given individual to sustain' (p. 81 my emphasis). Goffman justifies grounding his definition of stigma in 'the notion of the "normal human being"' by arguing firstly, that this is 'the basic imaginary' through which 'laymen currently conceive of themselves' (fn. 10, p. 7), and secondly, that we live in rational societies characterised by 'the tendency of large-scale bureaucratic organizations, such as the nation state, to treat all members in some respects as equal' (fn. 10, p. 7). Yet as he wrote this justification, millions of American citizens were explicitly contesting "the facts" of this equality, and "the forms" which 'a normal human being' could take (ibid.). As we have established Goffman was aware of ongoing social and political challenges to white normativity and racial 
stigma but refused to dwell on the political economy of stigma, noting that his 'is a statement about the social function of these processes and not about their cause or desirability' (pp. 129130).

Unsurprisingly, and perhaps accurately in the context of the United States in the early 1960s, Goffman reveals that the singular norm he is writing about (and from the perspective of) is 'that of the young, married, white, urban, northern' male (p. 128). 'There is only one complete unblushing male in America' he argues, and '[e]very American male tends to look out upon the world' from the perspective of heterosexual able-bodied white masculinity (p. 128). Goffman describes this white male norm as the 'general identity-values' of American society adding that this ideal identity casts a 'shadow on the encounters encountered everywhere in daily living' (p. 129). Goffman doesn't reveal the figure of "heterosexual able-bodied white masculinity" as the measure of 'general identity-values' until the reader is reaching the final chapters of Stigma. However, once the abstract normal collapses into the particularity of this figure, he grants us a key with which to unravel "the normal perspective" through and from which he produced his account of stigma. Given the strictures of this ideal human, people's potential to fail this norm, and be stigmatised as a consequence, is extensive. Goffman's cast of "stigma figures" includes the physically disabled, people with 'blemishes of individual character' such as 'weak will, domineering or unnatural passions, treacherous, mental disorder, imprisonment, addiction, alcoholism, homosexuality, unemployment, suicidal attempts' extending to 'radical political behavior' and those tainted by what he terms 'tribal stigma of race, nation, and religion' (1986, p. 4). Perhaps Goffman was reflecting on his own Jewish ethnicity, but it seems more likely he was reflecting on the stigma of being Black in the United States, when he added that 'tribal stigma' 'can be transmitted through lineages and equally contaminate all members of a family' $\left(1986\right.$, p. 4). ${ }^{x v}$

Goffman's figures for racial stigma include the 'educated northern Negro' (p. 44) who finds themselves mistaken for a Southern Negro, 'urban lower class Negroes' (p. 44), 'an apprehended Negro' (fn. 1 p. 46), 'black-skinned Negroes who have never passed publicly' (p. 74), and 'a passing Negro and the white girl he wants to marry' (fn. 101 p. 95). Goffman also comments on how skinlightening products are fraudulently sold as a remedy for the stigma of dark skin (p. 9), and reflects on the ambivalent social position of 'the light-skinned Negro' who 'can never be sure what the attitude of a new acquaintance will be' (p. 14). While Goffman suggests that many stigmas can be successfully concealed or managed, he reflects on the fact that visibly racialised minorities and members of the lower class 'who quite noticeably bear the mark of their status in their speech, 
appearance, and manner, and who, relative to the public institutions of our society find they are second class citizens' are 'all likely on occasion to find themselves functioning as stigmatized individuals' (p. 146). For sure, the version of white normativity which Goffman depicts in Stigma tallies with accounts such as W.E.B. Du Bois', who had argued two decades earlier in Dusk of Dawn: An Essay Toward an Autobiography of a Race Concept that being Black in America is to be 'badged' by colour, to be marked out 'for discrimination and insult' (Du Bois, 2007, p. 59, p. 126). However, what Black Sociology also tells us is that living as a person racialised as Black in the early 1960s didn't mean being stigmatised, 'on occasion', it meant daily confrontation 'with the realities of racism, not simply as individual acts dictated by attitudinal bias' but with an entire society organised through 'racial terrorism' (Davis, 2004, p. 496). Further, unlike his Black sociological elders and contemporaries, Goffman offers no account of why 'to be unconditionally "American" is to be white, and to be black is a misfortune', or how historical norms of white supremacy were being challenged as he wrote his book (Killian \& Grigg [1964] in Carmichael \& Hamilton, 1992, p. 31). Moreover, we reach a major contradiction in Goffman's account of racial stigma, when he suggests that there is a natural difference between what he terms the 'congenital' sign of skin colour and imposed social signs such as 'a brand mark or maiming' (1986, p. 46). Goffman is here not only illustrating existing racism in US society but also normalising racial difference as a "fact" which is consequent of deeper genetic human difference. Indeed, his argument that the 'congenital' "fact of blackness" is 'a permanent part of the person' (p. 46), seems to trouble Goffman's own conclusion in Stigma that 'the normal' and 'the stigmatized' are social roles -- and that anybody might find themselves in either role in a given (interactional) context (p. 46). For Goffman, blackness is a stigma which is it impossible to erase. A 'stigma of inferiority that resides not merely in the label or designation of race', but is imagined as 'embodied in black presence' (Williams, 1990, pp. 542-543). In this sense, the figure of the normal human in Stigma doesn't only describe existing social norms but reproduces what Lewis Gordon describes as 'the in-advance

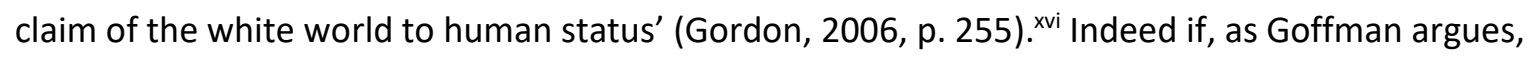
'we believe the person with a stigma is not quite human' (p. 5), then Black readers of Stigma find both that they are 'not structurally regarded as human beings' and that this dehumanised positionality is their permanent fate (Gordon, 2015, p. 22).

For many sociologists, what is appealing about Goffman's conceptualisation of stigma is precisely that it is relational, contextual, contingent and historically malleable. However, by taking Goffman "at his word", I have demonstrated that one of the limitations of his account is that he uses norms to obfuscate and naturalise existing arrangements of power. Goffman argues that 'we believe the 
person with a stigma is not quite human' and 'on this assumption we exercise varieties of discrimination, through which we effectively, if often unthinkingly, reduce his life chances' (Goffman, 1986, p. 5). He also stresses that the 'psychological price' of stigmatisation is 'living a life that can be collapsed at any moment' (1986, p. 108). However, he offers neither compassion nor space for imagining alternatives to the system of confining and discriminating norms he describes. Rather, he argues that normal and stigmatised people should 'accept' social norms: 'Not doing so, one could hardly get on with the business at hand; one could hardly have any business at hand' (1986?, p. 5). That this is a political recommendation is most evident in one of the final sections of Stigma, when Goffman makes a series of proposals about how individuals might manage living with stigma. This is one of the few places in the book that Goffman addresses the stigmatised rather than 'we normals'. His proposals to those suffering with stigma are conservative, pragmatic and-given the relational character of his theory of stigma -- oddly individualistic.

'Normals', Goffman reassures the stigmatised, 'really mean no harm', and 'should therefore be tactfully helped to act nicely' (p. 116). He argues that the stigmatised should not contest the norms that produce stigma, but instead develop strategies of stigma management in social settings where stigma might arise. Goffman's proposals for the stigmatised include 'information management' (1986, p. 135) 'the arts of impression management' (p. 130), employing strategies of 'passing and covering' (p. 130), adopting a position of 'tolerance' (p. 121) and refraining 'from pushing claims for acceptance much past the point normals find comfortable' (p. 130). As he writes, 'When the stigmatized person finds that normals have difficulty in ignoring his failing, he should try to help them and the social situation by conscious efforts to reduce tension' (p. 116). In the context of Goffman's larger oeuvre, we might understand these proposals on the management of stigma as dramaturgical-in the sense that they offer suggestions to the stigmatised about how to play an assigned social role which minimises the discomfort of 'normals', and in doing support, rather than challenge, the existing relations of power inscribed in social norms. Further, while Goffman cautions that the stigmatised should not 'ingratiatingly act out before normals the full dance of bad qualities imputed to his kind' (p. 110), he also advises they should play the parts society has assigned to them. To this end he quotes the Norwegian writer Finn Carling who, reflecting on his own experience of living with cerebral palsy, notes:

the cripple has to play the part of the cripple, just as many women have to be what the men expect them to be, just women; and the Negroes often have to act like clowns in front of the 'superior' white race, so that the white man shall not be frightened by his 
black brother (in Goffman, 1986, p. 110).

What we learn from Goffman is that for people racialised as Black, "managing a spoiled identity" means interacting in public in ways which protects white people from 'the ferocious mythology of blackness... as the embodiment of inferiority' (Williams, 1990, p. 543). In order to decolonise Goffman's stigma concept, it is imperative that we question why he is so seemingly invested in maintaining an arrangement of normal-stigma relations in which only people who are socially marked as white can be normal. We also have to question why Goffman remained so empathically silent about the struggles against anti-Black racism -- struggles which precisely sought to challenge white normativity by disrupting racist norms of social interaction - while they were unfolding all around him - including in his own classroom.

\section{'A Black Boy Hacked into a Murderous Lesson'}

Reading Stigma through the lens of Black freedom struggles it is possible to discern 'the strategies of power that are immanent' within Goffman's stigma theory (Ferguson, 2004, p. 55). In effect, by arguing for the management of stigma, that is for its pacification, Goffman normalises stigma and conceals 'its violent underpinning and periodic atrocities' (Steinberg, 2007, p. 42). From this perspective, Goffman's stigma concept 'is not innocent of politics, but on the contrary, provides epistemic authority' for the suppression of Black humanity (ibid.).

To take just one example, the Greensboro Four and many others amongst the Black students who would follow them in staging sit-in protests across the segregated Southern states, were haunted by the lynching of 14-year-old Emmett Till in Mississippi in 1955-indeed Joyce Ladner coined this generation of civil rights activists 'the Emmett Till generation' (Ladner, Ladner \& Mosnier, 2011). Born and raised in Chicago, Till was visiting relatives in the small town of Money, when he allegedly wolf whistled at a white woman ${ }^{\text {xvii }}$ in a Grocery store. Seemingly unaware of 'the subtleties of the Jim Crow Mississippi code of racial etiquette' (Rubin, 1995, p. 45), for this crime of alleged flirtation he was abducted, tortured, maimed and shot. His mutilated body was later recovered from the Tallahatchie River. Till's mother insisted her son's corpse be displayed in an open coffin in order, in her words, to 'rip the sheets off the state of Mississippi' (Mobley \& Benson, 2004, p. 151). However, the terrible violent truth exposed by the circulation of photographs of Till's disfigured body, and the later acquittal of his killers by an all-white jury, left many Black teenagers fearful, angry and despairing. For this generation of young Black citizens, 
images of Till's body functioned as both an image of injustice and, as Audre Lorde put it, as a 'veiled warning'-- a 'black boy hacked into a murderous lesson' (Lorde, 2002, p. 340).

The death of Till, the publicity surrounding his death and the acquittal of his killers, reveals how whiteness as a 'general identity-value' cast its long shadow over Black lives in the 1960s (Goffman, 1986 p. 129). Franklin McCain described Till's death as a revelation which left his 15 -year-old self in a suicidal depression: 'there seemed no prospect for dignity or respect as a young black man' (Younge, 1999, p. 108). This was a context where Black people daily negotiated interactional settings where not playing your socially assigned role as a racially stigmatised person, failing to appropriately manage your racial stigma by reducing tensions in your interactions with white people, could led to your death. As Khazan recalled, this murder revealed 'what happened if we broke the code. If we spoke out of turn, we too could die like Emmett Till' (Cerese \& Channing, 2003). The haunting of this generation by the lynching of Emmett Till illustrates how stigma power works to confine and segregate, to keep people 'down and away' (Link \& Phelan 2014, p. 26). However, it also reveals how the violence of being stigmatised can become politicised and act as a catalyst for social change. Joyce Ladner describes, as a teenager, keeping a scrapbook of cuttings about Emmett Till which she would regularly weep over in her bedroom. As she states 'That was the image for our generation that galvanised our generation, we all saw that image on the front cover of Jet magazine... Every black southerner for sure had seen that photograph and it was like the clarion call for action... when we got older we were going to avenge his death' (Ladner, Ladner \& Mosnier, 2011). Ladner would later bring this activism to bear on the discipline of sociology itself, laying bare, in her edited volume The Death of White Sociology (1973), the white norms and racial-bias at the heart of the discipline.

\section{Stigma as Struggle}

Resituating Goffman's stigma concept within the context of Black freedom struggles against 'the legal stigma of second class citizenship' has revealed how his understanding of stigma proceeds from what was then, as now, a deeply contested understanding of white prototypicality and Black inhumanity (Marable, 2000 p. 106). While Goffman's stigma concept uncouples the perception of Black skin as a stigma from the history of racism - and specifically in the US the history of slavery, Black freedom struggles remind us that racial stigmatisation is a historical practice 'centuries in the making' (Spillers, 2003, p. 21). A regime of seeing, a 'stigma-optics', which was crafted in order to deny Black people personhood (Tyler, forthcoming). As Carmichael put it in his 'Black Power' 
speech to students at Berkeley in October 1966, 'we are now engaged in a psychological struggle in this country... The question is, 'How can white society begin to move to see black people as human beings?' (Carmichael, 1966).

What is of interest--- both sociologically and politically ---is not only how stigma is lived and managed but how it is refused, reworked and resisted by those whom it abjects (Tyler, 2013). While Black (and disabled) readers of Goffman's Stigma find themselves not structurally regarded as human beings in this text, we also know that in 1963 many millions of Black American citizens sought 'to win recognition as human outside of the restrictive terms set by the racial order' (Gilroy, 2014, p. 7). By targeting the interaction order, their struggles made visible the concrete ways in which white supremacy invaded 'the lives of Black people on an infinite variety of levels' (Davis 2004, p. 496). As James Boggs noted this was unlike the preceding Civil Rights Movement of the 1950s in that 'it aimed at creating the issue, provoking it' (Boggs, 2011, p. 135). What Black activists realised is that in order to challenge 'the stigmata of degradation' they needed to remediate racial stigma (Du Bois, 1933, p. 199). Breaking the social rules around segregation, these Black activists provoked violent forms of stigmatisation. In doing, they crafted new perceptual frames for understanding the operations of racial discrimination. Reflecting on what motivated him to join the sit-in movement as a teenager in 1960, Stokley Carmichael recalls how: 'when I saw those kids on TV, getting back up on the lunch counter stools after being knocked off them, sugar in their eyes, catsup in their hair-well, something happened to me. Suddenly I was burning' (Park, 1967, p. 80). As Abdelmalek Sayad notes:

Black American sociology and colonial sociology teach that, as a general rule, one form of revolt, and undoubtedly the primary form of revolt against stigmatization [...] consists in reclaiming the stigma, which then becomes an emblem of [resistance]. (Sayad, 2006, p. 173, my translation).

Through acts of stigma dramaturgy, the Civil Rights Movement publicised, revolted against and reversed the power of stigma.

\section{Conclusion: Stigma After Goffman}

In 1963, the year Stigma was published, the pioneering Black sociologist and activist W.E.B Du Bois died in exile in Accra, Ghana - the U.S. government had confiscated his passport. After Du Bois' death, 'Maya Angelou led a group of Americans and Ghanaians to the U.S. embassy in Accra, 
carrying torches and placards reading "Down with American Apartheid" and "America, a White Man's Heaven and a Black Man's Hell"' (Euchner, 2010). A day later, at the March on Washington, Roy Wilkins, leader of the National Association for the Advancement of Colored People (NAACP) led a minutes silence in remembrance of Du Bois. As he stated to the hundreds of thousands of marchers 'his was the voice that was calling to you to gather here today in this cause. If you want to read something that applies to 1963 go back and get a volume of The Souls of Black Folk by Du Bois, published in 1903' (Euchner, 2010)..viii While Goffman didn't reference him, Du Bois was the first theorist of stigma power, identifying not only 'the problem of the Twentieth Century as the problem of the colour-line', but detailing how this line was enforced, reproduced and legitimated by the 'systematic humiliation' of Black lives (Du Bois, 2015, p. 1, p. 8).

There is a growing recognition that 'racism and intellectual segregation' have not only limited and divided the sociological tradition, but continue to diminish the capacity of the discipline to comprehend the key problems of the twenty-first century' (Back \& Tate, 2015). When Goffman was teaching at Berkeley this segregation was challenged by Black students, as it is today in the transnational "Why is My Curriculum White?" movement. In the spring of 1961 a group of Berkeley students formed a reading group, the Afro-American Association, which crafted an alternative "Black Curriculum" featuring the work of scholars such as Du Bois, Frantz Fanon, James Baldwin, E Franklin Frazier and Kwame Nkrumah (Kelley, 2016). This group soon extended their activities into the wider community, running a weekly radio programme that attracted other Bay area college and university students, including Huey Newton and Bobby Seale who went on to form the Black Panthers. At the same time, in segregated Black universities in the Southern states, such as Tougaloo College in Mississippi, Black sociology students like Anne Moody, Joyce Ladner and their professors became active participants in the sit-in movements. Indeed, Jibrel Khazan of the Greensboro Four was also a sociology major. Together these students, activists and scholars were busy producing sociological knowledge about stigma, and developing anti-stigma strategies, which included the psychologically reparative work of protest itself (Taylor, 2016).

Of central importance to these Black freedom struggles was Carmichael and Hamilton's antistigma concept of 'Black Power' which reconfigured racial stigma into 'a revolutionary emotion': 'We aim to define and encourage a new consciousness among black people' they wrote, and facilitate 'a sense of peoplehood: pride, rather than shame, in blackness' (Carmichael \& Hamilton, [1967] 1992, p. ix, p. viii). ${ }^{\text {xix }}$ In arguing that racial stigma functions as a form of psycho-social governmental power, Carmichael and Hamilton stressed the historic relationship between stigma 
and capitalism (racial capitalism), one which persists and continues to be resisted today. Indeed, as Jenna Loyd and Annie Bonds argue in this issue, Black Lives Matter marks another conjunctural moment in the history of racial capitalism in the United States - a period Michelle Alexander has coined 'The New Jim Crow' (Alexander, 2010).

Despite the sophisticated understanding of racial stigma developed over a hundred years of Black sociological thought, the conceptualisation of stigma in sociology has largely been 'structured by the absence of an address' to this tradition (Bhambra, 2014a, p. 12). Recent scholarship suggests a renewed sociological interest in the relationship between racism, stigma and power (see Loury, 2003; Howarth, 2006; Matory, 2015; Lamont et. al., 2016). In seeking to historically resituate Goffman's original account, this paper has drawn on a longer and wider range of interlocutors working in a Black sociological tradition, including Mario Biondi, James Boggs, Stokley Carmichael, Patricia Hill Collins, Angela Davis, Kimberley Dotson, W.E.B. Du Bois, Roderick Ferguson, Frantz Fanon, the Greensboro Four, Paul Gilroy, Lewis Gordon, Charles Hamilton, Harry Haywood, Robin Kelley, Joyce Lamont, Manning Marable, Zine Magubane, Anne Moody, Cedric Robinson, Hortense Spillers, Cornell West, Patricia Williams and Gary Younge. The account of stigma which emerges through this Black genealogy of stigma-thinking challenges the individualism of psychological approaches to social problems, exposes the limits of Goffman's white normative perspective, and troubles "race neutral" forms of interactional analysis. What this scholarship offers in place of a Goffman-esque approach, are rich historical, political and economic conceptualisations of stigma as technologies of de-humanisation, and stigma as a form of power which has been collectively resisted from below. It is the argument of this paper that bringing racism and anti-racist scholarship to the front and centre of sociological understandings of stigma not only enriches its utility as an analytic for understanding racism but also other forms of "dehumanisation" - such as classist, disablist and misogynist practices -- which are also grounded in eugenicist and/or essentialist ideologies of human difference.

\section{References}

Alexander, M. (2010). The New Jim Crow: Mass Incarceration in the Age of Colorblindness. New York: The New Press.

Andrews, K., \& Biggs, M. (2006). The Dynamics of Protest Diffusion: Movement Organizations, Social Networks, and News Media in the 1960 Sit-Ins. American Sociological Review, 71 (5), $752-$ 777. 
Back, L. \& Tate. M. (2015). For a Sociological Reconstruction: W.E.B. Du Bois, Stuart Hall and Segregated Sociology. Sociological Research Online, 20 (3). Retrieved from http://www.socresonline.org.uk/20/3/15.html

Bhambra, G. (2014). A sociological dilemma: Race, segregation and US sociology. Current Sociology, $62(4), 472-492$.

Bhambra. G. (2014a). Connected Sociologies. London: Bloomsbury.

Biondi, M. (2014). The Black Revolution on Campus. Berkeley: University of California Press.

Boggs, J. (2011). Pages from a Black radical's notebook: A James Boggs reader. S. Ward (Ed.). Detroit: Wayne University Press.

Boyd, H. (2004). We Shall Overcome With 2 Audio CDs: The History of the Civil Rights Movement as It Happened. Naperville: Sourcebooks MediaFusion.

Butler, J. (1993). Bodies That Matter: On the Discursive Limits of Sex, London and New York: Routledge.

Carmichael, S. (1966). Black Power Speech. University of Berkeley. Retrieved from https://www.youtube.com/watch?v=dFFWTsUaEaY

Carmichael, S., \& Hamilton, C. ([1967] 1992). Black Power: The Politics of Liberation in America. New York: Vintage.

Caroll, R. (2017, January 27). Woman at center of Emmett Till case tells author she fabricated testimony. The Guardian. Retrieved from https://www.theguardian.com/usnews/2017/jan/27/emmett-till-book-carolyn-bryant-confession

Cerese, R., \& Channing, S. [Directors] (2003). February One: The Story of the Greensboro Four. Independent Lens. 
Collins, P. (2007). Pushing the Boundaries or Business as Usual? Race, Class, and Gender Studies and Sociological Inquiry. In C. Calhoun (Ed.), Sociology in America: A History (pp. 572-604). Chicago: University of Chicago Press.

Davis, A. ([1970] 2004). Political Prisoners, Prisons, and Black Revolution. In H. Zinn \& A. Arnvoce (Eds.). Voices of a People's History of the United States (pp. 494-498). New York: Seven Stories Press.

Dotson, K. (2011). Tracking Epistemic Violence, Tracking Practices of Silencing. Hypatia, 26 (2), 236-257.

Du Bois, W.E.B. ([1903] 2015). The Souls of Black Folk. New Haven Connecticut. Yale University Press.

Du Bois, W.E.B. (1916). The Looking Glass. The Crisis: A Record of the Darker Races, 13 (2), 81-87.

Du Bois, W.E.B. (1933). On Being Ashamed of Oneself: An Essay on Race Pride. The Crisis: A Record of the Darker Races, 40, (9) 199-200.

Du Bois, W.E.B. ([1940] 2007). Dusk of Dawn: An Essay Toward an Autobiography of a Race Concept. Oxford: Oxford University Press.

Euchner, C. (2010). Excerpt: Roy Wilkins's Reluctant Tribute to W.E.B. Du Bois. Retrieved from http://www.beaconbroadside.com/broadside/2010/08/excerpt-roy-wilkinss-reluctant-tribute-toweb-du-bois.html.

Fanon, F. ([1952] 2008). Black Skin, White Masks. Translated by C. Markmann. London: Pluto.

Ferguson, R. (2004). Aberrations in Black: Towards a Queer of Color Critique. Minneapolis: University of Minnesota Press.

Fleming, C., \& Morris, A. (2015). Theorizing Ethnic and Racial Movements in the Global Age: Lessons from the Civil Rights Movement. Sociology of Race and Ethnicity, 1 (1), 105-126. 
Freeman, J. (2004). At Berkeley in the Sixties: The Education of an Activist, 1961-1965.

Bloomington: Indiana University Press.

Gilroy, P. (2002). There Ain't No Black in the Union Jack: The Cultural Politics of Race and Nation. London, New York: Routledge.

Gilroy, P. (2014). Race and Racism in "The Age of Obama": The Tenth Annual Eccles Centre for American Studies Plenary Lecture given at the British Association for American Studies Annual Conference, 2013. London: The British Library.

Goffman, E. (1956). The Presentation of Self in Everyday Life. Edinburgh: University of Edinburgh.

Goffman, E. (1961). Asylums: Essays on the Social Situation of Mental Patients and Other Inmates. New York: Anchor.

Goffman, E. ([1963] 1986). Stigma: Notes on the Management of a Spoiled Identity. New York: Simon \& Schuster.

Goffman, E. (1982). The Interaction Order: American Sociological Association, 1982 Presidential Address. American Sociological Review, 48 (1), 1-17.

Gordon, L. (2006). Is the Human a Teleological Suspension of Man? Phenomenological Exploration of Sylvia Wynter's Fanonian and Biodicean Reflections. In A. Bogues (Ed.), After Man, Towards the Human: Critical Essays on the Thought of Sylvia Wynter (pp. 237-257). Kingston, JA: Ian Randle.

Gordon, L. (2015). What Fanon Said: A Philosophical Introduction to His Life and Thought. London: Hurst \& Company.

Haywood, H. (1948). Negro Liberation. New York: International Publishers.

Howarth, C. (2006). Race as stigma: positioning the stigmatized as agents, not objects. Journal of Community and Applied Social Psychology, 16 (6), 442-45.

Hunt, P. (1966). A Critical Condition. In Hunt, P. (Ed.), Stigma: The Experience of Disability (pp. 145159). London: Geoffrey Chapman. 
Jameson, F. (1976). On Goffman's Frame Analysis. Theory and Society, 3, 119-133.

Joseph, P. (2014). Stokely: A Life. New York. Basic Civitas.

Kelley, R. (1996). Race Rebels: Culture, Politics, and the Black Working Class. New York: Free Press.

Kelley, R. (2016). Cedric J. Robinson: the Making of a Black Radical Intellectual. Counterpunch, June 17. Retrieved from https://www.counterpunch.org/2016/06/17/cedric-j-robinson-the-making-ofa-black-radical-intellectual/.

Khazan, J. (N.D.) Interview. International Civil Rights Center \& Museum Greensboro. Retrieved from http://www.sitinmovement.org/.

Ladner, J. (1973). The Death of White Sociology. New York: Random House.

Ladner, D., Ladner, J., \& Mosnier, J. (2011). Dorie Ann Ladner and Joyce Ladner oral history interview conducted by Joseph Mosnier in Washington, D.C., $20^{\text {th }}$ September. Retrieved from https://www.loc.gov/item/afc2010039_crhp0054/.

Lamont, M., Silva, G., Welburn, J., Guetzkow, J., Mizrachi, N., Herzog, H., \& Reis, E. (2016). Getting Respect: Responding to Stigma and Discrimination in the United States, Brazil, and Israel. Princeton: Princeton University Press.

Langer, E. (2014, January 13). Franklin McCain, who helped inspire sit-ins for civil rights as part of Greensboro Four, dies. Washington Post. Retrieved from https://www.washingtonpost.com/national/franklin-mccain-who-helped-inspire-sit-ins-for-civilrights-as-part-of-greensboro-four-dies/2014/01/13/8c39840e-7c6e-11e3-95564a4bf7bcbd84_story.html?utm_term=.f06a3b64c22e.

Link, B., \& Phelan, J. (2014). Stigma Power. Social Science \& Medicine, 103, 24-32.

Lorde, A. (2002). The Collected Poems of Audre Lorde. New York: W.W. Norton. 
Loury, G. (2003). The Anatomy of Racial Inequality. Harvard: Harvard University Press.

Love, H. (2010). Feeling Bad in 1963. In J. Staiger, A. Cvetkovick \& A. Reynolds (Eds.), Political Emotions (pp. 112-133). London, New York: Routledge.

Love, H. (2013). Close Reading and Thin Description. Public Culture, 25 (3), 401-434.

Magubane, Z. (2016). American Sociology's Racial Ontology: Remembering Slavery, Deconstructing Modernity, and Charting the Future of Global Historical Sociology, Cultural Sociology, 10 (3), 369384.

Marable, M. (2000). How Capitalism Underdeveloped Black America: Problems in Race, Political Economy, and Society. London: Pluto.

Marx. G. (1984). Role Models And Role Distance: A Remembrance of Erving Goffman. Theory and Society, 13 (5), 649-662.

Matory, J. (2015). Stigma and Culture: Last-Place Anxiety in Black America. Chicago: University of Chicago Press.

Meier, A., \& Rudwick, E. (1973). CORE: A Study In the Civil Rights Movement, 1942-1968. New York: Oxford University Press.

Mobley, M., \& Benson, C. (2004). Death of Innocence: The Story of the Hate Crime That Changed America. New York: Ballantine.

Moody, A. (1968). Coming of Age in Mississippi. New York: Dial.

Murch, D. (2010). Living for the City: Migration, Education, and the Rise of the Black Panther Party in Oakland, California. Chapel Hill: The University of North Carolina Press.

Park, G. (1967, 19 May). 'Whip of Black Power'. Life Magazine, 76-82.

Robinson, C. (1997). Black Movements in America. New York. Routledge. 
Robinson, C. (2000). Black Marxism: The Making of a Black Radical Tradition. Chapel Hill: University of North Carolina Press.

Rubin, A. (1995). Reflections on the Death of Emmett Till. Southern Cultures, $2(1), 45-66$.

Sayad, A. (2006). L'Immigration ou les paradoxes de l'altérité. L'illusion du proviso ire. Paris: Raisons d'agir.

Schweik, S. (2014). Stigma Management. Disability Studies Quarterly. 34 (1). Retrieved from http://dsq-sds.org/article/view/4014/3539.

Spillers, H. (2003). Black, White, and in Color: Essays On American Literature and Culture. Chicago: University of Chicago Press.

Steinberg, S. (2007). Race Relations: A Critique. Stanford: Stanford University Press.

Taylor, K. (2016). From \#BlackLivesMatter to Black Liberation. Chicago: Haymarket Books.

Taylor, S., Bogdan, R. \& DeVault, M. (2016). Introduction to Qualitative Research Methods: A Guidebook and Resource. New Jersey: John Wiley.

Tyler, I. (2013). Revolting Subjects: Social Abjection and Resistance in Neoliberal Britain. London: Zed.

Tyler, I. (2017). The Hieroglyphics of the Border: Racial Stigma in Neoliberal Europe, Ethnic and Racial Studies, eprint online.

Tyler, I. (forthcoming). Stigma Machines. London: Zed.

West, C. ([1987], 2016). Race and Social Theory: Towards a Genealogical Materialist Analysis [extract]. Retrieved from http://www.versobooks.com/blogs/2568-race-and-social-theorytowards-a-genealogical-materialist-analysis.

West, N. (1933). Miss Lonelyhearts. New York: Avon. 
Williams, P. (1990). Metro Broadcasting, Inc. v. FCC: Regrouping in Singular Times. Harvard Law Review, 104 (2), 525-546.

X, M. (1964). Malcom X in Cairo Urges African Aid to U.S. Negroes. The Militant. Retrieved from http://hierographics.org/malcolmX.htm.

Younge, G. (1999) No Place Like Home: A Black Briton's Journey Through the American South. London: Picador.

Younge, G. (2013, 07 May). 1963: The defining year of the Civil Rights Movement. The Guardian. Retrieved from https://www.theguardian.com/world/2013/may/07/1963-defining-year-civilrights.

\footnotetext{
${ }^{\mathrm{i}}$ North Carolina A\&T State University was then a segregated Black university, it was established on March 9, 1891 as "The Agricultural and Mechanical College for the Colored Race". In 1969 a confrontation between the National Guard and student activists on this campus culminated in what Martha Biondi described as 'the most massive armed assault ever made against and American university', when the Army was drafted in to raid a male dormitory, which resulted in hundreds of students taken into police custody (Biondi, 2014, p. 158).

ii I am using Jibreel Khazan's chosen name here, but in 1960 he was known by his birth name Ezell Blair.

iii Sit-ins against anti-Black racism and segregation can be traced back to 1943 when Congress of Racial Equality (CORE) activists occupied a Chicago restaurant that refused service to Black customers (see Meier \& Rudwick, 1973; Andrews \& Biggs, 2006).

iv US television news footage of the sit-in movement from 1963, including some clips from Greensboro, can be viewed on the NBC online news archive here: http://www.nbcnews.com/video/today-in-history/22886961\#22886961.
}

${ }^{\vee}$ There are interesting parallels between this moment in US television history, and the importance of mobile media, such as smart phones, in documenting and distributing footage of police violence against Black citizens and \#Blacklivesmatter protests in the US today.

vii I have chosen to use Stokley Carmichael's birth name, rather than Kwame Ture, to reflect the name he used during the period of activism and in the writings referenced in this article.

ix The Free Speech Movement burst onto UC Berkeley campus in 1964, inspired first by the Civil Rights Movement, and later student-led opposition to the Vietnam War (see Freeman, 2004).

${ }^{x}$ This student would have been in an extremely small minority at Berkley in 1961. It is estimated that there were only 100 Black students enrolled at the University in 1960, out of a student 
population of 20,000 . Historical accounts of the University from this period describe the deep alienation experienced by Black students, both in terms of their minority status on campus, and in terms of the whiteness and the conservatism of academic curriculums (see Murch, 2010).

${ }^{x i}$ As Heather Love notes, his 'primary method of abstract synthesis is supplemented, perhaps even challenged, by the trace of the embodied, affective experience of social others, both fictional and real, archived in his footnotes' (Love, 2010, p. 118).

xiii See 'Forum Introduction: Reflections on the Fiftieth Anniversary of Erving Goffman's Stigma' (2012) in Disability Studies Quarterly for reflections on Goffman and Hunt's different contributions to thinking disability stigma.

xiv See for example Judith Butler's (1993) inspired work on the power of gender norms.

xvii In 2017 Carolyn Bryant admitted that the testimony she gave in court, namely that Till had sexually harassed her, was untrue (see Caroll, 2017).

xix The transnational genealogical threads of Black epistemologies of stigma power are fascinating and important to note here. For example, it is in Frantz Fanon's work that we find the most developed understanding of racial stigma as a penal technology - an explanation of how and why the modern history of anti-Black racism came to be written on the skin. Fanon was born in the French colony of Martinique, but later renounced his French citizenship. Fanon in turn inspired Stokley Carmichaels' development of the concept of Black Power - while Fanon was himself indebted the writing of Du Bois, Richard Wright and James Baldwin. 